\begin{abstract}
Iranica
Abstracta Iranica Revue bibliographique pour le domaine irano-aryen

Volume 40-41 | 2019

Comptes rendus des publications de 2017-2018
\end{abstract}

\title{
Kevin Van Bladel. « Zoroaster's Many Languages »
}

\section{Samra Azarnouche}

\section{(2) OpenEdition}

\section{Journals}

\section{Édition électronique}

URL : http://journals.openedition.org/abstractairanica/50858

DOI : 10.4000/abstractairanica.50858

ISBN : 1961-960X

ISSN : 1961-960X

Éditeur :

CNRS (UMR 7528 Mondes iraniens et indiens), Éditions de l'IFRI

Référence électronique

Samra Azarnouche, « Kevin Van Bladel. "Zoroaster's Many Languages » », Abstracta Iranica [En ligne], Volume 40-41 | 2019, document 14, mis en ligne le 30 décembre 2019, consulté le 21 avril 2021. URL http://journals.openedition.org/abstractairanica/50858; DOI : https://doi.org/10.4000/ abstractairanica.50858

Ce document a été généré automatiquement le 21 avril 2021.

Tous droits réservés 


\title{
Kevin Van Bladel. « Zoroaster's Many Languages »
}

\author{
Samra Azarnouche
}

\section{RÉFÉRENCE}

Kevin Van Bladel. « Zoroaster's Many Languages » in Joseph E. Lowry, Shawkat M. Toorawa (eds.). Arabic Humanities, Islamic Thought. Essays in Honor of Everett K. Rowson. Leiden-Boston: Brill, 2017, p. 190-210 (Islamic History and Civilization, Studies and Texts 141)

1 Dans sa description de l'Avesta, Ibn al-Nadīm fait allusion au fait qu'il été écrit dans «toutes les langues ». L'A. fait l'hypothèse que sa source a été une épître polémique du savant Qusțā ibn Lūqā, selon qui l'Avesta contiendrait toutes les sciences et chaque mot était écrit dans une langue différente. Le fameux Ādurbād Ēmedān aurait été son informateur.

2 L'A. analyse par la suite les récits des auteurs chrétiens de l'Église d'Orient selon qui Zoroastre connaissait tantôt sept, tantôt douze langues. Une question reste en suspens : Ceci peut-il être le reflet d'une réalité de la tradition exégétique zoroastrienne?

Deux remarques s'imposent: dans la réponse d'Ādurfarnbag au chrétien dans le Dēnkard V.24.12, il est question de la supériorité de l'oralité sur l'écrit, et non de la polyglossie de l'Avesta (qui est dit inclure tous «les sons du monde », hamāg āwāz). Le thème des sept idiomes des Persans se retrouve dans des textes du 19e s., notamment chez Pétis de la Croix (Relation de Dourry Efendi, 1810, p. 121). 


\section{AUTEURS}

SAMRA AZARNOUCHE

EPHE, Mondes iranien et indien, Paris 